\title{
Chemistry of chlorite from the K-silicate-sericitic alteration in Elatsite porphyry $\mathrm{Cu}$-Au deposit, Bulgaria
}

\section{Химичен състав на хлорит от К-силикатно-серицитовата промяна в медно-порфирно находище Елаците, България}

\author{
Hristiana Georgieva ${ }^{1}$, Rossen Nedialkov ${ }^{2}$ \\ Християна Георгиева ${ }^{1}$ Росен Недялков ${ }^{2}$ \\ ${ }^{1}$ Geological Institute, Bulgarian Academy of Sciences, Akad. G. Bonchev St., bl. 24, 1113 Sofia; \\ E-mail: ch_georgieva@geology.bas.bg \\ ${ }^{2}$ Sofia University St. Kliment Ohridski, 15, Tzar Osvoboditel Blvd., 1504 Sofia; E-mail: rned@gea.uni-sofia.bg
}

\begin{abstract}
The K-silicate-sericitic alteration is one of the well-preserved hydrothermal alterations at the Elatsite porphyry-copper gold deposit (PCGD). It is observed in all lithological varieties, but shows asymmetric distribution of the secondary products. The alteration is genetically related with the occurrence of the K-silicate and Na-Ca-K-silicate alteration. The K-silicate-sericitic alteration has simple mineral content which includes mainly chlorite and sericite. The temperature of formation of the alteration is estimated between $250-268^{\circ} \mathrm{C}$.
\end{abstract}

Keywords: Porphyry-copper deposit, chlorite, K-silicate-sericitic alteration, Elatsite.

The Elatsite porphyry $\mathrm{Cu}-\mathrm{Au}$ deposit (PCGD) is situated at the northernmost part of the Srednogorie zone, which is a part of the Apuseni-Banat-TimokSrednogorie copper belt (Popov et al., 2000). It is operating since 1983-1984 and is one of the biggest deposits in Europe with estimated 185 million tons resources with $0.45 \% \mathrm{Cu}, 0.3 \mathrm{~g} / \mathrm{t} \mathrm{Au}, 0.0046 \% \mathrm{Mo}$, $375 \mathrm{~g} / \mathrm{t}$ Re and up to $1.9 \mathrm{~g} / \mathrm{t} \mathrm{Ag}$ (González-Jiménez et al., 2021).

The deposit is genetically related with Upper Cretaceous porphyritic dike-like, east-west elongated pluton intruded into the regional basement of low-grade Paleozoic schists and the disposed into them Variscan Vezhen pluton (Popov et al., 2012). The main Upper Cretaceous porphyritic rocks are presented by quartz monzodiorites and granodiorites as well as quartz diorites (von Quadt et al., 2002).

During the years of exploitation several schemes of associations of hydrothermal alterations in the Elatsite PCGD have been suggested (Popov et al., 2000; Kanazirski et al., 2002; Georgiev, 2005, 2019; Nedialkov et al., 2012; Ivanov et al., 2014; Georgieva et al., 2019). The hydrothermal alteration products, related with the porphyritic magmatism, are represented by propylitic, K-silicate, K-silicatesericitic, sericitic, quartz-adularia-carbonate alterations, Na-Ca alteration, Na-Ca-K-silicate (transitional between $\mathrm{Na}-\mathrm{Ca}$ and $\mathrm{K}$-silicate alteration) and skarn formation.

The aim of the present study is to give comparative characteristics of chlorite from the K-silicatesericitic alteration and give new data for chlorite developed on black micas from $\mathrm{Na}-\mathrm{Ca}-\mathrm{K}$-silicate alteration.

The K-silicate-sericitic alteration is the most common alteration in the deposit. It is characterized by the typical for K-silicate alteration texture of replacement of the mafic minerals by a multitude of fine-grained secondary black mica that latter is replaced partially or completely by sericite or chlorite. This type of alteration is observed in all lithological varieties, but it is common for the granodiorites of the Vezhen pluton as well as in the porphyries. Some asymmetric spatial distribution of the alteration can be observed with wider spread of the secondary products in the west and northwest parts of the deposit. Usually the K-silicate-sericitic al- 

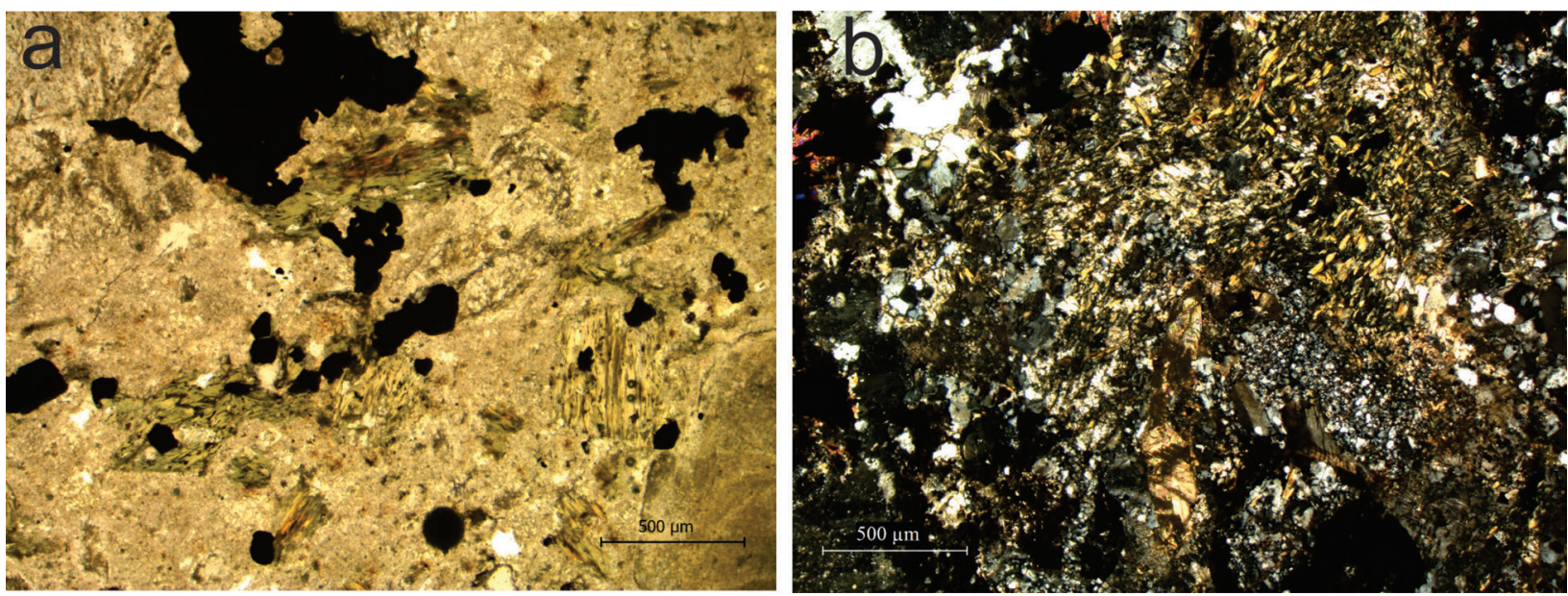

Fig. 1. Microphotography of chlorite from K-silicate-sericitic alteration: $a$, chlorite developed on secondary phlogopite from $\mathrm{K}$-silicate alteration (Chl II), plane-polarized light; $b$, chlorite developed on secondary mica from Na-Ca-K-silicate alteration (Chl II-I), cross-polarized light

teration is well preserved and is affecting the whole rock volume, but sometimes the magmatic texture is preserved. Typically for this alteration is the presence of secondary chlorite/sericite developed after the secondary black mica from K-silicate or Na-Ca$\mathrm{K}$-silicate alterations. Their occurrence corresponds to the stage after the formation of K-silicate alteration and precedes quartz-sericitic alteration.

At least two types of the alteration can be distinguished: dominated by chlorite or dominated by sericite. The most common type is the one with chlorite prevalence, while sericite-dominated is relatively rare and difficult to separate from the quartzsericitic alteration. Nevertheless, some differences of the mesoscopic characteristics can be observed. For example, the rocks with chlorite-dominated alteration, are darker, although the black (dark) minerals have lost their lust. The alteration dominated by sericite makes the rocks brighter.

Chlorite from the chlorite dominated variety usually forms fine-grained aggregates, with pale green color under the microscope and the type of partition is related to the presence of secondary black mica from the K-silicate alteration or from $\mathrm{Na}-\mathrm{Ca}-\mathrm{K}$-silicate alteration (Fig. 1). Some differences in the mineral chemistry of chlorite developed on the black mica from K-silicate alteration (Chl II) and one developed on mica from $\mathrm{Na}-\mathrm{Ca}-$ $\mathrm{K}$-silicate alteration (Chl II-I) are determined. On the classification diagram of Hey (1954) Chl II is described as pycnochlorite to penninite, with $\mathrm{Fe}^{*}$ ratio $0.21-0.48$ (Fig. 2). The various Fe content is related to that in the secondary black mica. The highest values are presented in chlorite, developed on secondary phlogopite from $\mathrm{Na}-\mathrm{Ca}-\mathrm{K}$-silicate alteration (Chl II-I). In Chl II are detected low values of REE. The chondrite-normalized patterns of REE for Chl II do not show clear trend, although. Chl II developed on secondary phlogopite shows higher values for REE, Rb, U, Ta, Nb. Chl II-I is relatively rare at the deposit, it has $\mathrm{Fe}^{*}$ ratio $0.56-0.62$, on the classification diagram it is presented as ripidolite to pycnochlorite (Fig. 2). Chl II-I has lower values for $\mathrm{Si}, \mathrm{Mn}, \mathrm{Ca}, \mathrm{K}, \mathrm{Cl}$ than Chl II.

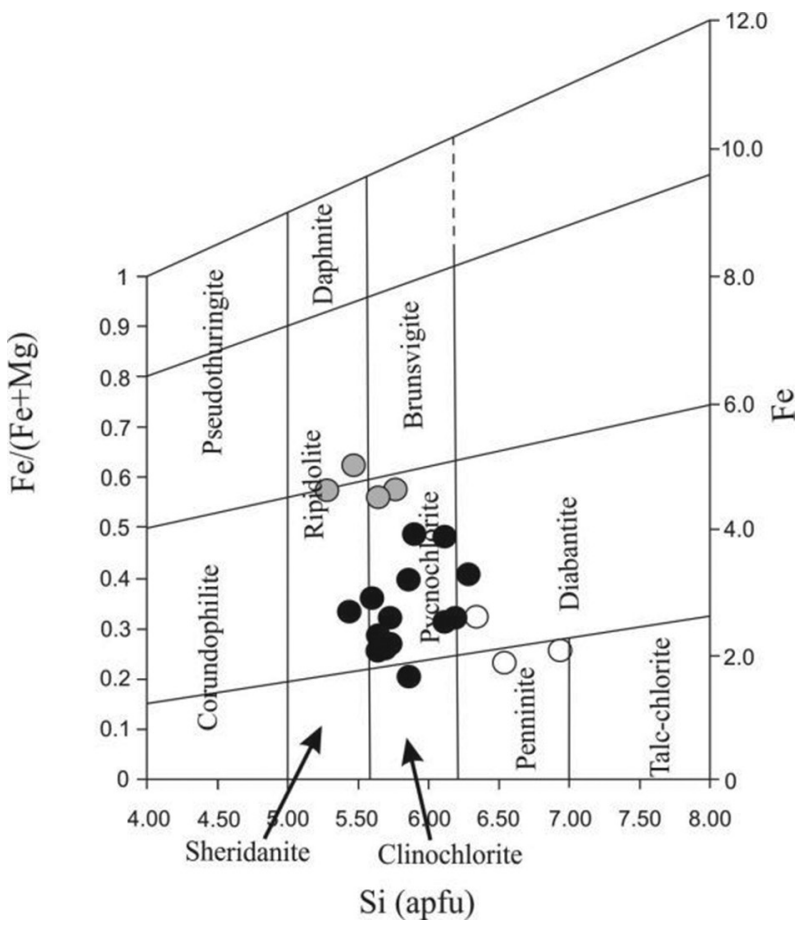

Fig. 2. Classification diagram for chlorites from the K-silicatesericitic alteration (Hey, 1954): black circles, Chl II developed on secondary phlogopite on primary biotite; white circles, Chl II developed on secondary phlogopite developed on primary amphibole; grey circles, Chl II-I 
The temperatures of crystallization of the two chlorites (Chl II and Chl II-I) are calculated using the thermometer of Cathelineau and Nieva (1985). The estimated temperatures are average $268{ }^{\circ} \mathrm{C}$ for $\mathrm{Chl} \mathrm{II}$ and $250{ }^{\circ} \mathrm{C}$ for $\mathrm{Chl}$ II-I. The temperatures correlate with the estimations of Ivanov et al. (2014) of 250-290 ${ }^{\circ} \mathrm{C}$.

Compared with the other alteration products the minerals from the $\mathrm{K}$-silicate-sericitic alteration are well preserved at the surface of the deposit. Although the most common alteration shows simple mineral assemblage, differences in the chemistry of the chlorite can be distinguished. The chemistry of the newly formed chlorites inherits some characteristics of the primary and secondary minerals on which it develops. The twice refined mineralogy of the rocks probably results in the low values for all the REE and rare elements (Georgieva, Nedialkov, 2017). Despite the differences in the mineral chemistry, the temperatures of formation of the secondary chlorite are equal.

Acknowledgements: This work was supported by the Bulgarian Ministry of Education and Science under the National Research Programme "Young scientists and postdoctoral students" approved by DCM \# 577 / 17.08.2018. The study is partly supported also by the KP-06-N44/4 project, financed by the Bulgarian National Science Fund.

\section{References}

Cathelineau, M., D. Nieva. 1985. A chlorite solid solution geothermometer the Los Azufres (Mexico) geothermal systems. - Contrib. Miner. Petrol., 91, 235-244; https://doi. org/10.1007/BF00413350.

Georgiev, G. 2005. Geological Model of the Elatsite deposit. PhD thesis, Sofia, Univ. Mining and Geol., 162 p. (in Bulgarian).

Georgiev, G. 2019. Hydrothermal Metasomatites in Elatsite Porphyry Copper Deposit. Sofia, Scientific and Technical Union of Mining, Geology and Metallurgy, 99 p.
Georgieva, H., R. Nedialkov. 2017. Chlorite from Elatsite PCD as a mineral vector. - Goldschmidt Abstracts 2017, p. 1319.

Georgieva, H., R. Nedialkov, I. Krumov. 2019. Hydrothermal amphiboles from $\mathrm{Na}-\mathrm{Ca}$ and $\mathrm{Na}-\mathrm{Ca}-\mathrm{K}$-silicate alterations: An example from Elatsite porphyry copper-gold deposit, Bulgaria - Proc. Geologica Carpath., 70, 65-68.

Gonzales-Himenes, J. M., R. Pina, T. Kerestedjian, F. Gervilla, I. Borrajo, J. Farre-de Pablo, J. Proenza, F. Tornos, J. Roque, F. Nieto. 2021. Mechanism for Pd-Au enrichment in porphyry-epithermal ores of the Elatsite deposit, Bulgaria. -J. Geochem. Explor., 220, 106664, 1-20.

Hey, M. 1954. A new review on chlorites. - Mineral. Mag., 30, 277-292; https://doi.org/10.1180/minmag.1954. 030.224 .01 .

Ivanov, Z., R. Nedialkov, K. Bogdanov. 2014. Magmatic and ore-related breccias in the Elatsite porphyry-copper deposit (PCD), Bulgaria. - Proc. XX Congress CBGA, Special Issue, $158-161$

Kanazirski, M., S. Chipchakova, M. Gorova, R. Arnaudova. 2002. Wallrock alterations in the porphyry copper deposits of the Panagyurishte ore district and formation-facial belonging of the metasomatites. - Geologica Balc., 32, 77-80.

Nedialkov, R., N. Hadzhieva, P. Vassileva. 2012. Geology and petrography of magmatic and magmatic-hydrothermal breccias in porphyry-copper deposit Elatsite. - Geology School of Bulgaria "The School of Prof. Z. Ivanov". Sofia, National Museum Earth and Men, 53-56.

Popov, P, R. Petrunov, V. Kovachev, S. Strashimirov, M. Kanazirski. 2000. Elatsite-Chelopech ore field - In: Strashimirov, S., P. Popov (Eds.). Geology and Metallogeny Features of the Panagyurishte Ore Region (Srednogorie Zone, Bulgaria). ABCD, GEODE 2000 Workshop, Borovets, Bulgaria, 19-25.

Popov, P., S. Strashimirov, K. Popov, M. Kanazirski, K. Bogdanov, R. Radichev, S. Dimovski, S. Stoykov. 2012. Geology and Metallogeny of the Panagyurishte Ore Region. Sofia, Univ. Mining and Geol., 228 p. (in Bulgarian with English abstract).

von Quadt, A., I. Peytcheva, B. Kamenov, L. Fanger, A. Heinrich, M. Frank. 2002. The Elatsite porphyry copper deposit in the Panagyurishte ore district, Srednogorie zone, Bulgaria: $\mathrm{U}-\mathrm{Pb}$ zircon geochronology and isotope-geochemical investigation of the magmatism and ore genesis. - In: Blundell, D. J., F. Neubauer, A. von Quadt (Eds.). The Timing and Location of Major Ore Deposits in an Evolving Orogeny. London, Geol. Soc. Spec. Publ., 204, 119-135; https:// doi.org/10.1144/GSL.SP.2002.204.01.08. 